Arbi Yasin, Adaptasi Sosial Keagamaan...

\title{
ADAPTASI SOSIAL KEAGAMAAN MASYARAKAT LOKAL DI LINGKUNGAN PEDESAAN BENGKALIS-RIAU
}

\section{Arbi Yasin}

\begin{abstract}
Abstrak: Kajian proses adabtasi ini akan terkait erat dengan fenomena perubahan ekologi di kawasan lokal pedesaan Bengkalis-Riau, yakni secara obyektif tidak bisa terlepas dari keterkaitannya dengan pengaruh lingkungan serta agama yang merupakan keyakinannya. Dalam proses adabtasi, manusia dituntut untuk senantiasa menyelaraskan perilakunya sebagai konsekuensi perubahan evolusioner lingkungan mereka yang bertujuan untuk survival, meminimumkan entropi serta sekaligus menjaga keseimbangan dinamis (steady state). Masyarakat lokal Bengkalis memiliki kebudayaan yang khas, membedakan mereka dengan kebudayaan masyarakat pendatang, di antaranya adanya pengaruh hinduisme dan animisme yang cukup lama dan panjang di dalam pranata sosial religi serta daur ritual mereka seperti; bersemah ladang, perencisan lancang, mati tanah, tepuk tepung tawar, buang betemas, tetelor dan lainsebagainya. Dengan demikian, beragamnya masyarakat lokal di pedesaan BengkalisRiau dipengaruhi oleh lingkungan fisik eksternal yang menyerap nilai-nilai budaya yang bersumber dari berbagai kepercayaan dan agama yang dianut masyarakat lokal melayu bengkalis sebelumnya.
\end{abstract}

Kata-kata kunci: Agama, sosiologi, ekologi dan masyarakat

Abstract: Study of adaptation process will closely be related with phenomena of ecological change in rural local area of Bengkalis Riau, namely that it can not be apart from its determination to environmental and religious influences. In adaptation process, people are demanded to harmonize their behavior as consequence of evolutional change of their environment that lead to survive,

118 Al-Fikra: Jurnal Ilmiah Keislaman, Vol. 3, no.1, Januari-Juni 2004 
Arbi Yasin, Adaptasi Sosial Keagamaan...

minimize its entropy, and maintain steady state as well. The local community of Bengkalis has specific custom that makes them different from other comer community. For instance, among the others, long influences of Hinduism and Animism in their socialreligious institutions and rites like bersemah ladang, perencisan lancang, mati tanah, tepuk tepung tawar, buang betemas, tetelor, etc. Thus, plurality of local community of rural Bengkalis Riau is affected by external environments that absorb cultural values of different believes and religions in which local Malay community of Bengkalis adhered before.

Key words: Religion, sociology, ecology and community

$$
\begin{aligned}
& \text { الملخص: إن دراسة عملية التكيف تتعلق كثيرا بظاهرة الإكولوحيا في الإقليم المحلى لقرى بنكالس }
\end{aligned}
$$

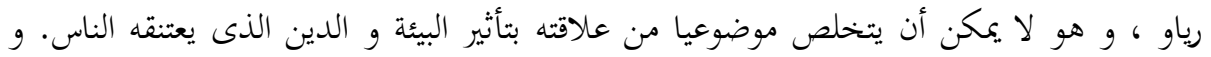

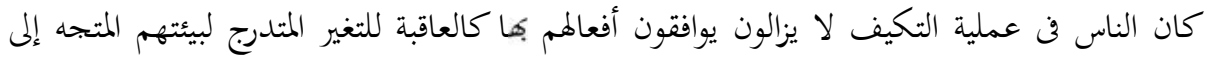

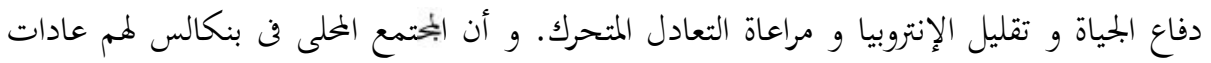

$$
\begin{aligned}
& \text { خاصة تميزهم من الآخرين القادمين إلى بلادهم. منها وجود آثار الهند و الأرواحية الطويلة في في فركئ }
\end{aligned}
$$

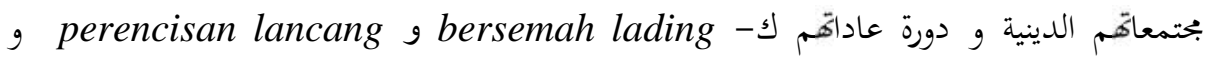

$$
\begin{aligned}
& \text { و و غيرها من العادات. و لذلك فإن تنوع البختمعات } \\
& \text { المحلية في قرى بنكالس رياو تؤثرها بيئة خارجية تمتص القيم الثقافية الصادرة من العقائد و الأديان }
\end{aligned}
$$

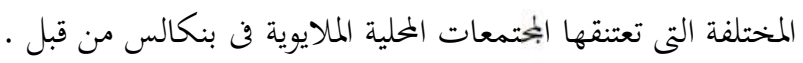

Faktor utama yang mendorong penulis untuk membahas masalah ini secara cermat adalah kondisi obyektif masyarakat, yang tidak bisa terlepas dari keterikatannya dengan "proses adaptasi dan pengaruh lingkungan serta agama yang merupakan keyakinannya. 
Arbi Yasin, Adaptasi Sosial Keagamaan...

Kondisi obyektif masyarakat seperti itu merupakan modal dasar yang sangat berarti dalam tulisan ini, karena penulis bertitik tolak dari sebuah pemikiran bahwa kondisi masyarakat merupakan gejala-gejala yang paling vital dalam kajian disiplin "ekologi manusia", terutama dari segi kehidupan keagamaan yang menjadi sentral pembahasan pada karya ilmiah ini.

Diantara tiga dimensi kondisi masyarakat secara obyektif itu, adaptasilah yang mendominasi topik pembahasan terpenting, mengingat adanya kenyataan tentang perubahan ekologis yang berlangsung secara terus-menerus dan terjadi sepanjang waktu pada lingkungan hidup manusia, sehingga proses-proses penyesuaian diri menjadi penting untuk terus dilakukan manusia tersebut.

Dalam proses adaptasi manusia dituntut untuk senantiasa menyelaraskan perilakunya sebagai konsekuensi perubahan evolusioner lingkungan mereka. Soerjani dan Bahrin Samad mengatakan "adaptasi adalah proses untuk memenuhi beberapa syarat dasar tertentu untuk dapat melangsungkan kehidupannya dalam lingkungan tempatnya hidup "(Soerjani dan Bahrin Samad : 1983).

Oleh karenanya "survival" adalah tujuan utama manusia beradaptasi. Adaptasi dalam rangka meminumkan entropi serta menjaga keseimbangan dinamis (steady state) dan terkait dengan konsep homeostasis Masyarakat setempat (lokal).

Masyarakat lokal di pedesaan Bengkalis-Riau, mayoritas beragama Islam. Mereka lebih suka memiliki agama Islam sebagai "Way of Life" atau pegangan hidupnya, ketimbang agama Katolik, Protestan, Hindu, Budha, dan Aliran Kepercayaan atau Kebatinan. Etnis yang masuk dalam kategori masyarakat lokal di Kabupaten Bengkalis itu adalah kebanyakannya etnis Melayu.

Masyarakat lokal Bengkalis memiliki Kebudayaan yang khas, yang membedakan mereka dengan kebudayaan masyarakat pendatang (etnis bangsa lainnya). Ciri-ciri kebudayaan 
Arbi Yasin, Adaptasi Sosial Keagamaan...

masyarakat lokal tersebut adalah : menggunakan bahasa Melayu, agama Islam, memiliki berbagai adat istiadat berkenaan dengan lingkungan hidup dan memiliki adat istiadat yang berkenaan dengan pengaturan kehidupan keluarga dan masyarakat, ramahtamah, mementingkan hidup kekeluargaan dan secara ekonomis tidak agresif atau tidak rakus (Hurmain DKK, 1997).

Dalam masyarakat lokal di daerah ini sangat terasa suasana keagamaanya. Beberapa penduduk yang saling mengenal masih sering bertegur sapa saat bertemu di jalan. Pada kesempatan tertentu seperti Idul Fitri, Idul Adha, hari-hari Besar Islam, Kenduri, Khitanan atau dalam pesta perkawinan, hampir setiap rumahtangga saling membantu dan bekerjasama memasak di dapur, bapak-bapak dan pemuda-pemuda gotong-royong menerima tamu dan meramaikan acara dan memimpin upacara keagamaan.

Ada satu dua tempat bersejarah yang dikeramatkan dan dijadikan tempat ziarah di pedesaan Bengkalis. Sekalipun jumlahnya semakin berkurang, masih ada penduduk yang menggunakan pakaian tradisional yang penuh muatan religius, seperti: peci, sarung, kebaya dan kemeja panjang (baju kurung tutup belanga).

Sebagian besar masyarakat lokal di pedesaan Bengkalis secara teguh menjalankan tradisi dan adat resam serta ajaran agama Islam. Adiwibowo (1983) mengatakan "suatu sistem sosial yang memiliki nilai-nilai dan norma-norma yang mampu mengatur anggotanya berperilaku selaras dengan lingkungannya akan menampilkan suatu totalitas kehidupan sosial dan ekologis yang khas".

Suatu totalitas kehidupan sosial dan ekologis yang khas pada masyarakat lokal di pedesaan Bengkalis-Riau, yaitu masyarakat lokal yang merupakan homogen etnis-suku yang beragama Islam, beradat- istiadat Melayu dan berbahasa Melayu (Amir Luthfi : 1991).

121 Al-Fikra: Jurnal Ilmiah Keislaman, Vol. 3, no.1, Januari-Juni 2004 
Arbi Yasin, Adaptasi Sosial Keagamaan...

Jadi masyarakat lokal di pedesaan Bengkalis-Riau terkenal sebagai orang-orang ta'at beragama dan orang-orang yang kuat berpegang pada adatnya. Agama dan adat bagi orang-orang lokal sudah melembaga, menyatu menjadi satu dalam eksistensinya. "Tak Islam, maka tak orang lokal", demikian orang-orang lokal menata kehidupan mereka dengan prinsip itu tadi.

Apakah masyarakat lokal di pedesaan Bengkalis-Riau itu, beragama dipengaruhi atau ditentukan oleh faktor lingkungan alam atau faktor lingkungan fisik eksternal (deterministik lingkungan), mengingat kesimpulan hasil penelitian Huntington (dalam Sanapiah Faisal dan Nur Yasik, tanpa tahun, hal : 91) yang mengatakan "faktor kondisional, lingkungan alam serta iklimiah sebagai determinan perubahan-perubahan sosial yang terjadi". Inilah fokus utama tulisan Saya pada kesempatan ini.

\section{II}

\section{Agama Pada Masyarakat Lokal Di Pedesaan Bengkalis}

Sulit membuat definisi mengenai masyarakat lokal ini, mengingat penduduk Bengkalis berkembang secara dinamis dan kompleks. Said Rusli (1996 : 7) mengatakan perkembangan penduduk terutama karena pengaruh sosek wilayah bersangkutan, yaitu: perubahan penduduk merupakan hasil dari kondisi sosial ekonomi penduduk yang bersangkutan (teori transisi demografi)".

Namun demikian dapat dibuat rumusan sederhana sebagai berikut; masyarakat lokal adalah mereka yang sudah menetap selama lebih dari dua generasi, dan ini berbeda dengan masyarakat pendatang, mereka adalah generasi sebelumnya menetap di luar Kabupaten Bengkalis. Semakin lama generasi sebelumnya menetap, semakin asli kelokalannya masyarakat tersebut, dan sebaliknya semakin singkat waktu menetap, semakin mereka mendekati kategori penduduk pendatang (Lola Wagner dan Danny Irawan Yatim : 1997).

122 Al-Fikra: Jurnal Ilmiah Keislaman, Vol. 3, no.1, Januari-Juni 2004 
Arbi Yasin, Adaptasi Sosial Keagamaan...

Baik orang-orang yang tinggal di pedesaan-pedesaan maupun yang tinggal di kota Bengkalis, masih dapat digolongkan ke dalam golongan-golongan asal yang lebih terbatas atau sempit lokasinya, yaitu dengan menggunakan kerangka acuan berdasarkan atas tempat atau pusat kerajaan melayu di masa lampau dan tempat asal kelahiran atau orang tua (Pulau, Kepulauan, Desa, Kampung, Kecamatan dan Kabupaten) yang biasanya digunakan dalam interaksi diantara sesama mereka yang berbeda asal.

Kerangka acuan tersebut menurut Pasurdi Suparlan (1995) mempunyai makna karena mengacu kepada ciri-ciri kebudayaan dan kepribadian, sebagaimana mereka sendiri mendefinisikannya, yang bersumber pada latarbelakang corak perkembangan sejarah dan kebudayaan yang ada dalam masing-masing tempat asal tersebut.

Dalam kehidupan masyarakat lokal yang ada di perkotaan, kerangka acuan tersebut menjadi penting dalam peranannya sebagai alat atau saluran untuk dapat saling tolong-menolong dan tetap dapat mempertahankan berbagai adat istiadat yang harus mereka lakukan. Berbagai perkumpulan yang berlandaskan atas asal yang sama banyak terdapat di kota Bengkalis.

Hampir seluruh mereka itu beragama Islam dan di tengah masyarakat tersebut telah berkembang pula "Tarekat" atau "Aliran mistik" dalam Islam di pedesaan Bengkalis-Riau. Masjid dan Mushalla telah pula dibangun dan mempunyai perlambang dan makna batin tersendiri bagi penganut agama besar ini.

Ditarik dari peranan agama bagi masyarakat lokal di Kabupaten Bengkalis, terutama di desa-desa sangatlah besarnya. Agama pula saat ini yang dapat menyatukan masyarakat lokal dengan penduduk pendatang sesama umat Islam, serta menjembatani jurang antara generasi muda dengan generasi tua. Walaupun sebagian pemuka agama mengakui bahwa pendalaman agama di kalangan generasi muda sudah menurun 
Arbi Yasin, Adaptasi Sosial Keagamaan...

(tingginya entropi) namun tidak sampai mengurangi pengaruh agama dalam berbagai kehidupan sosial kemasyarakatan.

\section{III}

\section{Agama: Pendekatan Deterministik Lingkungan Dan Beberapa Pendekatan Ekologi Manusia Lainnya}

Masyarakat lokal di pedesaan Bengkalis-Riau adalah masyarakat religius, homogen dan sekligus terkenal sebagai orang-orang yang kuat berpegang pada adatnya.

Adat resam masyarakat lokal Bengkalis-Riau amatlah sarat mengandung nilai-nilai luhur yang terpercaya, menjadi panutan pelakunya, merasuk ke dalam jiwa mereka sedemikian rupa. Adat itu berjalan dan tertus berlangsung secara kontiniu dari satu generasi ke generasi berikutnya, tanpa henti secara harmoni karena diikat dengan nilai-nilai religi dan bahkan sedikit berbau mistik dan religio-migic.

Hajar. M (1997) mengatakannya sebagai "agama profetis" yang diselubungi dengan "agama Islam" yang rapi, yang siap membentuk prilaku mereka dalam berbudaya, di tengah-tengah sosial kemasyarakatannya.

Kondisi itu jugalah yang menimbulkan istilah di kalangan mereka, "Tak Islam, Maka Tak Orang Lokal" seperti yang diutarakan di atas. Keadaan kondisi tersebut menyebabkan masyarakat lokal di pedesaan Bengkalis begitu kental dalam beragama di lingkungannya.

Kekentalan beragama itu disebabkan oleh kondisi lingkungan itu sendiri, artinya dengan memakai istilah aliran deterministik lingkungan, alamlah yang membuat mereka kuat dan kental beragama. Pertanyaan akan muncul, apakah alam yang membentuk kebudayaan beragama mereka ....?

Menurut pendekatan deterministik yang dipelopori oleh para ahli geografi seperti Ellen C. Semple (1911), Robert S. Platt (1948) dan Harold \& Margaret Sprout (1965), terjadinya

124 Al-Fikra: Jurnal Ilmiah Keislaman, Vol. 3, no.1, Januari-Juni 2004 
Arbi Yasin, Adaptasi Sosial Keagamaan...

kebudayaan karena dicetak oleh alam atau lingkungan. Pendekatan yang dipengaruhi oleh lahirnya aliran Darwinisme dan pendekatan Newton tentang deduksi dan konsepsi hubungan sebab akibat (lihat dalam Adiwibowo : 1983), dimana pendekatan ini melihat faktor-faktor yang mendukung terbentuk kebudayaan, yaitu faktor-faktor fisik alam (Physical environment) yaitu : Topograpy, geographical location, natural resources dan climate.

Huntington (dalam grossman : 1977) iklim dan cuaca sebagai faktor-faktor yang mempengaruhi perkembangan manusia dan masyarakat.

Pendekatan possibilisme lingkungan yang dikembangkan oleh Kroeber (1939), Arnold Toynbee (1947), Harold \& Margaret Sprout (1965) dan Moris Treilich (1967) pada dasarnya faktor lingkungan bukan determinan faktor, tetapi faktor lingkungan hanyalah sebagai "penapis, penyaring atau sceen" terbentuknya unsur budaya tertentu (cultural traits).

Sedangkan pendekatan ekologi budaya (cultural ecology) sebagai perevisi pendekatan posibilisme lingkungan. Pendekatan ini dikembangkan oleh Julian H. Steward (1968), Clifford Geerzts (1963) dan Marvin Harris (1966). Menurut Adiwibowo (1983), Steward ini ingin memperjelaskan hubungan timbal balik yang terjadi antara kebudayaan dan lingkungan (seperti dalam pendekatan posibilisme lingkungan) melalui penelaahan dari sudut adaptasi. Steward memandang dinamika organisasi sosial budaya sebagai produk dari proses adaptasi manusia dengan lingkungannya. Pada kondisi lingkungan tertentu akan tumbuh beberapa pranata atau institusi yang berpola tertentu, yang dikenal sebagai "Inti Kebudayaan" atau cultural core. Inti kebudayaan ini dapat merupakan pranata sosial, budaya atau ekonomi. Inti kebudayaan ini tumbuh berkat adanya "teknologi eksploitasi sumberdaya" dan organisasi sosial yang bergerak di bidang pengelolaan sumberdaya tersebut. 
Arbi Yasin, Adaptasi Sosial Keagamaan...

Elemen cultural core adalah population patterns, economic organitation dan exploitative technology. Sementara yang menjadi elemen "non-core elements of culture" adalah religion, language, art dan values. Menurut pendekatan ini cultural core terbentuk dari pengaruh ekologi (ecologycal influences yang ada di lingkungan alam (natural environment). Sedangkan non-core elements of culture terbentuk dari difusi sifat-sifat pembawaan (trait diffusion from other societies) yang ada di lingkungan sosial (social melieu). Baik cultural core maupun non-core elements of culture akan mempengaruhi terbentuknya sistem sosial politik (socio-political system) suatu masyarakat (Rambo, 1981 : figure, 3). Penjelasan Rambo terhadap konsep Steward tentang ekologi budaya dipertegas oleh Adiwibowo (1983), bahwa inti budaya yang dimaksudkan oleh Steward (1968) dapat merupakan pranata sosial, budaya atau ekonomi.

Selanjutnya pendekatan Model Ekosistem (Sistem Ekologis), yang dikembangkan oleh Andrew P. Payda dan Roy Rappaport, yaitu untuk melihat bagaimana kebudayaan beradaptasi dengan lingkungan atau populasi manusia yang beradaptasi dengan lingkungan ekologi. Menurut Adiwibowo (1983) ciri utama pendekatan ini terletak pada penerapan konsep ekologi dalam analisis dinamika perilaku manusia dengan lingkungan sekitarnya. Pendekatan ini menggunakan ekosistem sebagai dasar analisis. Hubungan antara komponen fisik, biologis dan sosial budaya yang bersifat saling timbal balik diintergrasikan dalam suatu sistem analisis, yaitu "ekosistem". Bertitik tolak dari hal ini, studi ekologi manusia akan dapat didekati dari pendekatan sistem. Selanjutnya menurut pendekatan ini terdapatnya elemenelemen kebudayaan sebagai faktor kunci yang mengatur interaksi antara sosial budaya dan alam.

Ada dua pendekatan lagi yang berkaitan dengan pendekatan sistem yang dikemukakan oleh Adiwibowo di dalam kelas Bengkalis atau kuliahnya yaitu pendekatan sisitem dari 
Arbi Yasin, Adaptasi Sosial Keagamaan...

Rambo dan pendekatan progressive contextualization yang diterapkan oleh Vadia. (Adiwibowo, kuliah ekoman : 2002).

Pendekatan sistem terdiri dari sistem sosial dan sistem ekologi. Antara sistem sosial dan sistem ekologi saling berkaitan dan berinteraksi, keduanya merupakan suatu sistem terbuka dan hubungan keduanya bersifat timbal balik, bukan bersifat sebab akibat seperti ekologi budaya oleh Steward. Semua atribut sistem sosial merupakan produk hasil seleksi dan adaptasi dari alam ekosistem.

Sedangkan pendekatan progressive contextualization oleh Andrew P. Vayde (1982) tidak berbeda sebenarnya dengan pendekatan sistem. Pendekatan ini mengisi kelemahan pendekatan sistem. Mengingatkan kembali pada pihak-pihak yang menggunakan pendekatan sistem dalam dua hal, yaitu :

1. Interaksi antara manusia dengan lingkungannya, agar merupakan fokus utama penelitian.

2. Operasionalisasi yang tepat dari penelitian yang bersifat "lintas disiplin ilmu".

Adiwibowo (2002) menjelaskan dengan singkat bahwa pendekatan ini tidak memakai teori atau tidak mau direpotkan serta tidak ingin terkungkung atas teori yang telah ada, tersedia. Maju saja, lalu tanya dan amati (grounded research), catat apa adanya, lalu tanyakan pada pakarnya apa-apa yang dijumpai di lapangan.

\section{IV}

\section{Prosesi Ritual Dan Lingkungan Fisik Alam Masyarakat Lokal}

Kabupaten Bengkalis yang termasuk propinsi Riau yang disebut juga sebagai "Kota Terubuk" merupakan wilayah yang memiliki "natural resources" yang sangat melimpah. Di Kabupaten Bengkalis inilah dijadikan salah satu pusat sentral pengembangan Industri utama pemerintah Indonesia. 
Arbi Yasin, Adaptasi Sosial Keagamaan...

Akan tetapi pengembangan industri selama ini selalu saja menciptakan struktur sosial masyarakat lokal yang pincang, memberi dampak negatif atau tingginya entropi masyarakat setempat.

Pengembangan proyek industri selama ini terkesan belum menjamin terciptanya lingkungan yang saling menguntungkan "symbiose mutualism" antara masyarakat lokal dengan proyekproyek industri tersebut.

Dukungan proyek yang bersifat langsung terhadap masyarakat lokal belumlah terjadi sebagaimana yang diharapkan, bahkan kecenderungan kuat proyek-proyek industri tersebut melampaui target dan batas "Carrying Capasity" masyarakat lokal dan membentuk "Enclave" yang terpisah secara tajam dari lingkungannya, bila dilihat dari berbagai aspek seperti tingkat pendapatan, tingkat pendidikan dan gaya hidup, nilai-nilai agama, dan teradisi utama yang dijunjung tinggi serta bentuk hubungan sosial lainnya.

Soemarwoto (1977) memperkuatnya "di suatu daerah yang ada proyek industri yang telah jadi, resiko lingkungan yang ada antara lain: pensemaran air dan udara, menyusutnya usaha pertanian, terjadinya masyarakat terpisah (enclave) dengan karyawan pabrik tingkat atas, ketegangan sosial antara pendatang dan penduduk lokal, dan sistem nilai kebudayaan yang tidak mantap."

Struktur sosial yang demikian itu sangat rawan karena ditandai oleh "GAP " sangat lebar antara masing-masing pelapisan sosial dari segi pendapatan (ekonomi), pendidikan, pemukiman maupun dari segi orientasi nilai (sistem nilai) dan kemampuan merebut peluang (kompetitif) yang tercipta oleh proses pembangunan melalui industri tersebut.

Suawasono Heddy Dan Metty Kurniati (1996) mengatakannya sebagai "environmental Resistance" yaitu 
Arbi Yasin, Adaptasi Sosial Keagamaan...

sejumlah faktor pembatas lingkungan yang menghalangi terjadinya potensial biotek.

Hurmain (1997) berkesimpulan pengembangan industri di wilayah Riau berakibat dapat mengancam akar budaya agraris yang telah lama menjadi pola hidup sebagian besar masyarakat lokal, berubahnya ikatan dan fungsi sosial, terjadinya kesenjangan pandangan antara generasi muda dan tua, bergesernya norma-norma sosial dan agama.

Kesemuanya ini akan dapat mengakibatkan perubahan yang sangat mendasar pada pola perilaku dan sikap individu atau pola perilaku dan sikap kolektif masyarakat.

Mubyarto DKK (1992) menjelaskan "pengembangan industri di Riau Menggusur masyarakat lokal dan terjadilah "marginalisasi" penduduk asli atau pribumi".

Masyarakat lokal di pedesaan Bengkalis-Riau tersaing oleh masyarakat pendatang dan akhirnya terasing dari dunianya. Tak mampu beradaptasi dan berpartisipasi terciptalah apa yang dinamakan marginalisasi itu dan terisolasi.

Walaupun keberadaan masyarakat lokal Bengkalis-Riau marginal dan terisolir sudah sekian lama, mereka mempunyai kemampuan bermasyarakat sosial (gregariousness) seperti makhluk hidup lainnya (Utomo: 1997). Artinya mereka mengusahakan agar tingkat entropi berada pada taraf tertentu sehingga mereka dapat tetap hidup dengan lingkungan sekitarnya, beradaptasi untuk menjaga keseimbangan dinamis (steady state).

Taraf tertentu dari entropi yang harus dicapai yaitu entropiminimum (rendah), apabila entropi mencapai maksimum maka akan tercipta equelibrum state yakni available free energy tidak tersedia lagi untuk bekerja, dengan pemahaman sederhana terciptalah ketimpangan dan ketidak-teraturan itu. Seperti dikemukakan oleh Erwin Schordinger yaitu setiap sistem kehidupan dapat hidup atau survive karena secara kontiniu 
Arbi Yasin, Adaptasi Sosial Keagamaan...

mengusahakan atau mengupayakan entropi negatif dari lingkungan sekitarnya. Menurut Adiwibowo (1983) keseimbangan dinamis (steady state) pada tingkatan sederhana diwujudkan oleh homeostasis sepanjang waktu.

Pada bagian lain, Adiwibowo (1983) menyatakan "homeostasis adalah salah satu mekanisme sederhana dari usaha suatu sistem untuk mempertahankan kondisi steady atate tertentu. Seperti apa yang dikatakan oleh Odum (1971), istilah homeostasis dalam ekologi, merupakan istilah yang digunakan untuk menggambarkan kecenderungan sistem biologi untuk tetap bertahan terhadap adanya perubahan serta berada dalam keadaan keseimbangan dinamis (state of equilibrum atau pada kondisi entropi negatif) dengan sekitarnya. Atau menurut Ricklefs (1979), istilah yang digunakan untuk menerangkan kemampuan organisme untuk memelihara secara konstan kondisi internalnya terhadap berbagai jenis dan variasi faktor lingkungan eksternal. Setiap organisme dengan mekanisme dan efektivitas yang berbeda-beda pada taraf tertentu mempunyai sifat ini.

Bila kita hubungkan antara konsep homeostasis dengan disiplin ilmu sosial, homeostasis pada dasarnya, upaya mempertahankan diri agar dirinya tidak hancur apabila mendapat ancaman dari luar. Usaha tersebut tercermin dalam budayanya, yaitu cultural form, yang mungkin terbentuk dari : topography, geographical location, natural reseources dan climate, menurut pendekatan determinisme lingkungan.

Agama merupakan cultural form dari masyarakat lokal di pedesaan Bengkalis-Riau yang berfungsi sebagai pencipta homeostasis di lingkungannya.

Adiwibowo(2002) mengatakan agama banyak turun di Arab Saudi karena pengaruh situasi dan kondisi lingkungan alam fisiknya. Di Arab keadaanya sepi, terbentang lebar gurun pasir Sahara yang memutih, luas dan memikat hati. Banyak inspirasi timbul, memberi kesempatan masyarakat lokal merenung, 
Arbi Yasin, Adaptasi Sosial Keagamaan...

memahami dan memikirkan mengenai ciptaan Tuhan. Akihrnya timbulah agama besar tersebut.

Lebih jauh Adiwibowo (2002) menjelaskan pakaian Jubah Putih orang Arab yang merupakan pakaian religius dan wujud kebudayaan konkrit supaya terhindar dari sengatan terik matahari sebab pakaian putihlah yang dapat memantul sinar matahari tersebut dari tubuhnya, ini adalah konsep homeostasis dan adaptasi.

Selanjutnya Kluckhohn (dalam Bambang Utomo: 1998) religi atau sistem kepercayaan merupakan salah satu dari tujuh elemen kebudayaan yang universal yaitu cara manusia beribadah terhadap Tuhan atau "Super Natural Being".

Daur Ritual menurut Rappaport 1968 (dalam Keesing: 1992) memainkan peranan penting dalam mengatur hubungan kelompok-kelompok dengan unsur-unsur non-manusia dari lingkungan hidup terdekat dan unsur-unsur manusia dari lingkungan hidup yang agak terpisah.

Selanjutnya Rappaport 1970 dan 1971 (dalam Keesing: 1992) memandang peran ritus sebagai suatu homeostat seperti termostat pemanas dan sebagai suatu transducer yaitu mengubah informasi kompleks ke dalam tanda binary sederhana yaitu ya atau tidak.

Masyarakat lokal di pedesaan Bengkalis-Riau juga begitu, semua attribut lingkungan yang membentuk kebudayaan diwarnai dengan berfungsinya pranata religi, dengan kata lain, religi masyarakat lokal di pedesaan berperan sebagai homeostasis atau adaptasi dengan lingkungan alam fisiknya.

Pada proses mencari rezeki atau nafkah hidup, masyarakat lokal dengan berladang atau menangkap ikan di laut (nelayan), itulah yang biasa dilakukannya sebab sumberdaya alam tersedia untuk itu (natural resources).

Proses awal mencari tempat untuk membuka ladang atau sawah atau nanti memungut hasil atau menuai, selalu saja diikuti 
Arbi Yasin, Adaptasi Sosial Keagamaan...

dengan upacara-upacara tertentu atau prosesi ritual yang mereka istilahkan dengan "bersemah ladang".

Begitu juga dengan mencari ikan di laut sebagai nelayan yang turun-menurun, supaya terhindar dari malapetaka dan gangguan makhluk halus, dilakukan "perencisan lancang" atau sampan sedemikian rupa dengan upacara-upacara ritual khusus yang juga banyak variasinya.

Pada upacara kekerabatan, yang terlihat dari proses kelahiran sampai dengan perkawinan, terpantul prosesi ritual yang kental. Untuk membangun rumah di suatu lingkungan tertentu diadakan upacara "mati tanah" sampai nanti untuk mendiami rumah baru tersebut dilalui dengan prosesi ritual "tepung tawar pindah rumah" namanya.

Kalau ada anggota rumahtangga yang sakit, mereka akan mengadakan acara "buang tetemas atau tetelor" karena masyarakat lokal menganggap si sakit "tersampuk" atau "tertegor". Di sini agama biasanya dihubungkan dan diwarnai dengan mistik dan religio-magic, karena keterbatasan mereka mengatasi alam yang realita, yang ada dalam kehidupan mereka sehari-hari.

Contoh lain dapat pula kita tampilkan di sini yang lebih menarik yaitu berkembangnya begitu pesat "tarekat" atau aliran "mistik" yang mereka disebut "Bersulop". Baik masyarakat lokal laki-laki maupun perempuan banyak mengikuti pengajian ini secara rutin, mayoritas diikuti orang tua-tua, lokasi pengajian bersulop ini biasanya di tempat sunyi-sunyi jauh dari keramaian dan keributan kota. Ibadah yang biasa dilakukan sebagai ciri khasnya adalah "Zikrullah" dan banyak mengingat akan mati atau hari kemudian. Mereka mencari ketenangan dan ketentraman di desa pedalaman. Air untuk berwudlu alami dari sungai-sungai, parit-parit atau kolam besar yang mereka buat sedemikian rupa. Betapa alam telah membentuk pribadi, watak dan perangai mereka. Masyarakat lokal biasanya sopan-santun

132 Al-Fikra: Jurnal Ilmiah Keislaman, Vol. 3, no.1, Januari-Juni 2004 
Arbi Yasin, Adaptasi Sosial Keagamaan...

terhadap sesama, jujur dan lemah lembut berbicara sebab mereka terbentuk oleh alam dan agama.

Selanjutnya Sudirman (1997) mengatakan terjadinya persentuhan antara nilai-nilai budaya masyarakat lokal yang berasal dari Islam dengan budaya tradisional Hinduisme dan animisme melalui proses yang cukup panjang, bahkan menimbulkan pertentangan dan konflik yang lama, sebab keduanya saling menanamkan pengaruhnya dalam masyarakat lokal (Melayu) Bengkalis.

Dengan demikian, budaya Melayu Bengkalis dalam sejarah perkembangannya telah menyerap nilai-nilai budaya yang bersumber dari berbagai kepercayaan dan agama yang dianut masyarakat Melayu Bengkalis sebelumnya. Dalam realitas sosial norma-normanya sudah banyak mengalami pergeseran akibat desakan dari nilai-nilai serta norma Islam. Semenjak Islam hadir di tengah-tengah kehidupan masayarakat Melayu Bengkalis, hampir semua nilai serta norma berasaskan doktrin Islam, Islam mewarnai sisi serta sendi-sendi budaya Melayu Bengkalis, sehingga membentuk wujud budaya yang bersifat Islami. Tergeserlah nilai-nilai dan norma-norma tradisional, semenjak itu wujud budaya Melayu Bengkalis yang berjiwakan Islam menduduki posisi strategis dalam menata sikap dan perilaku pendukungnya dalam pranata sosial budaya dan sosial ekonomi masyarakat pendukungnya. Semenjak itulah lahirlah suatu ungkapan "Orang Melayu Beragama Islam, Beradat Istiadat Melayu Dan Berbahasa Melayu". Ungkapan tersebut menunjukan antara Islam dan budaya melayu menjadi satu kesatuan wujud, yang menjadikan syariat Islam sebagai substansi yang menggerakan semua organ tubuh budaya masyarakat lokal Melayu di pedesaan Bengkalis-RIau.

Berdasarkan prinsip di atas, timbul suatu pandangan dari masyarakat pedesaan Melayu Bengkalis-Riau terhadap syariat Islam sebagai suatu yang bernas dan bening, yakni suatu 
Arbi Yasin, Adaptasi Sosial Keagamaan...

pandangan yang melukiskan Islam sebagai bekal yang memberi jaminan untuk hidup dan mati dalam arti Islam memberi bekal untuk kehidupan duniawi dan ukhrawi. Dalam kehidupan duniawi Islam mengatur serta menata semua dimensi pranata sosial, baik yang berhubungan dengan Tuhan yang bersifat vertikal, maupun hubungan manusia sesamanya yang bersifat horizontal dan dengan alam sekitarnya. Karena itulah orang Melayu Bengkalis memandang kehidupan duniawi sangat penting artinya dalam menjalankan perintah Tuhan sebagai bekal dalam kehidupan ukhrawi kelak pada kemudian hari.

\section{Kesimpulan}

Telaahan proses adaptasi ekologis akan terkait erat dengan fenomena perubahan ekologi di kawasan masyarakat lokal di pedesaan Bengkalis-Riau, yakni secara obyektif tidak bisa terlepas dari keterkaitannya dengan pengaruh lingkungan serta agama yang merupakan keyakinannya.

Agama dan adat bagi masyarakat lokal Bengkalis-Riau sudah melembaga menyatu menjadi satu dalam eksistensinya : Tak Islam, Maka Tak Orang Lokal atau dengan suatu ungkapan “Orang Melayu Beragama Islam, Beradat-Istiadat Melayu Dan Berbahasa Melayu" ungkapan tersebut menunjukkan antara Islam dan budaya Melayu Bengkalis menjadi satu kesatuan wujud, yang menjadikan syariat Islam sebagai substansi yang menggerakan semua organ tubuh budaya masyarakat lokal Melayu di pedesaan Bengkalis-Riau.

Budaya sosial keagamaan masyarakat lokal di pedesaan Bengkalis itu tercermin juga adanya pengaruh hinduisme dan animisme yang cukup lama dan panjang, sedikit berbau mistik dan religio-magic, terlihat dalam pranata religi serta daur ritual yang khas seperti bersemah ladang, perencisan lancang, mati 
Arbi Yasin, Adaptasi Sosial Keagamaan...

tanah, tepuk tepung tawar, buang tetemas dan tetelor, tersampuk dan tertegor serta yang agak moderat berkembangnya begitu pesat "Tarekat" atau "Bersulop".

Dengan demikian, beragamanya masyarakat lokal di pedesaan Bengkalis-Riau dipengaruhi oleh lingkungan fisik eksternal (deterministik lingkungan) yang menyerap nilai-nilai budaya yang bersumber dari berbagai kepercayaan dan agama yang dianut masyarakat lokal Melayu Bengkalis-Riasu sebelumnya. Akan tetapi, dalam relaitas sosialnya, normanormanya sudah banyak mengalami pergeseran akibat desakan dari nilai-nilai Islam serta norma Islam yang datang terkemudian.

\section{DAFTAR PUSTAKA}

Abu Hasan Sham (a), Syair-Syair Melayu Riau, Kuala Lumpur, Perpustakaan Negara Malaysia, 1995

(b), Puisi-Puisi Raja Ali Haji, Kuala Lumpur, Dewan Bahasa dan Pustaka Kementrian Pelajaran Malaysia, 1987

Abdullah bin Abdul Karim Munsyi, Hikayat Abdullah, Jakarta, Djembatan, tt.

A.G. Priggodigdo, Ensiklopedi Umum, Yogyakarta, Kanisus, 1986.

Asiah Abu Samah, Emancipation of Malay Women (1945-1957), Singapura, B.A. Gradek, University of Malaya, 1960, h

Barbara Watson Andaya dan Viginia Matheson "Pemikiran Islam Dan Tradisi Melayu Tulisan Raja Ali Haji dari Riau (ca. 1809ca.1870), Dari Raja Ali Haji Hingga Hamka, terj. Th.Sumartahana, Jakarta, Grafiti Press, 1983

135 Al-Fikra: Jurnal Ilmiah Keislaman, Vol. 3, no.1, Januari-Juni 2004 
Arbi Yasin, Adaptasi Sosial Keagamaan...

E. Nietscher, De Nederlanders is Johor and Siak, (terj) Wan Galib at., all., Batavia, Bruinning and Wijt, 1870

Hasan Junus (a), Raja Ali Haji Budayawan Di Gerbang Abad XX, Pekanbar, UIR Prees, 1988

Hasan Junus (b), Gurindam Duabelas dan Sejumlah Sajak-Sajak Lain Raja Ali Haji, Pekanbaru, Yayasan Pusaka Riau, 2000.

(C), Pendokumentasian Naskah Kuno Melayu Riau dan Kajian Khusus, pekanbaru, Yayasan Setanggi bekerjasama dengan Bappeda Tk.I Riau, 1994.

, dkk., Raja Ali Haji Dan Karya-Karyanya, Pekanbaru, P2BKM, UNRI, 1996.

Muhammad Idris Abdur Rauf al-Marbawi, Kamus Idris Marbawi, Juz I, Semarang, Usaha Karya, tt.

Raja Ali Haji (a), Syair Siti Shianah, Pulau Penyengat, 1311. (Dalam bentuk manuskrip / tulisan tangan )

(f), Tuhfat al-Nafis, (ed) Virginia Matheson, Kuala Lumpur, Fajar Bakti, 1982.

U.U. Hamidy (a), Teks dan Pengarang Di Riau, Pekanbaru, UNRI Press, 1998

(b), dkk, Pengarang Melayu dalam Kerajaan Riau dan Abdullah bin Abdul Karim Munsyi dalam Sastra Melayu, Jakarta, Pusat Pembinaan dan Pengembangan Bahasa, Depdikbud, 1981.

136 Al-Fikra: Jurnal Ilmiah Keislaman, Vol. 3, no.1, Januari-Juni 2004 
Arbi Yasin, Adaptasi Sosial Keagamaan...

U.U. Hamidy (((c), “ Naskah Kuno Daerah Riau: Gambaran Kegiatan Cendekiawan Melayu dalam Bidang Bahasa, Sastra dan Kemasyarakatan", MMRK.

Yusuf al-Qardawi, Fiqih Zakat, Juz I, Beirut, Muassasah Risalah, 1991.

U.U. Hamidy, dkk., Pengarang Melayu dalam Kerajaan Riau dan Abdullah bin Abdul Karim Munsyi

137 Al-Fikra: Jurnal Ilmiah Keislaman, Vol. 3, no.1, Januari-Juni 2004 